\title{
The Practice Of Entrepreneurship Education Through Extracurricular Activities In Higher Education: Students Perspective
}

\author{
${ }^{1}$ Wudu Melese Tarekegne, ${ }^{2}$ Alebachew Hailu Gelaneh \\ ${ }^{1}$ Jimma University, Department of Teacher Education and Curriculum Studies Ethiopia, \\ ${ }^{2}$ Curriculum expert in Addis Ababa University South compus, Ethiopia. \\ wudumelese@gmail.com, alebea.h@gmail.com
}

\begin{abstract}
Purpose: This study was aimed at investigating the practice of entrepreneurship education through extracurricular activities in higher education from students perspective.

Design/methodology/approach: To achieve this objective descriptive survey research design was used.

Findings: The result shows that students have participated in extracurricular activities and have a willingness to participate if they get an opportunity. However, students did not participated in business plan competition, company visit, competition with external stakeholders, seminars and workshops.

Research limitations/implications: Four universities were selected as sample universities by using simple random sampling technique.

Practical implications: The major challenges identified are lack of funding available to support the entrepreneurship education, lack of support from the top management and the government and lack of teachers support and encouragement of student's practice of entrepreneurship education through extracurricular activities.
\end{abstract}

Originality/value:

Paper type: This paper can be categorized as case study paper.

Key words: Entrepreneurship education; extracurricular activity; Higher Education; Practice; Students

$\begin{array}{lll}\text { Received } & : & \text { July } 12^{\text {th }} 2019 \\ \text { Revised } & : & \text { August } 15^{\text {th }} 2019 \\ \text { Published } & : \text { September } 30^{\text {th }} 2019\end{array}$

\section{INTRODUCTION}

Nowadays, entrepreneurship has turned into one of the most significant university activities. Moreover, its key role in progress of societies has made many universities in developed and developing countries take utilizing entrepreneurship into account. Also, by developing strategies, policies, and scientific programs, they can step towards lifting and reinforcing students' entrepreneurship spirit and behavior through effective training (Ahmad, 1999). Training in entrepreneurship is an activity utilized to communicate knowledge and information required for setting and running businesses. In addition, it enhances, improves, and develops non-entrepreneurs' attitudes, skills, and abilities (Zabihi, 2006).Training in entrepreneurship affects the level of trends,

The Practice Of Entrepreneurship Education Through Extracurricular Activities In Higher Education: Students Perspective 
activities, and entrepreneurial passion, as a result of which setting and developing new businesses in economy is also affected (Zali, Yadollahi, \& Kordnaee, 2010).

The importance of universities in the task of orienting graduates to develop their entrepreneurial intention has been stressed by numerous researchers. Over the years researchers have tried to provide an answer to these questions: What, How and When to teach at universities in order to foment entrepreneurial initiative? (Kirby, 2005; Buckland, 2009; De Silva, 2015). Taking into account the importance of entrepreneurship in the economy (Acs \& Szerb, 2007), universities devote considerable effort to developing both curricular and extracurricular activities to encourage entrepreneurial intention in their students (Shinnar et al., 2009; Davey et al., 2010; Ertuna and Gurel, 2011; Thomas et al., 2014).

However, university entrepreneurial education has continuously over-looked the role of practice as an epistemological means of learning, and how practice can contribute to entrepreneurial development, which is different from traditional approaches (Higgins, et al, 2013). Entrepreneurship education has come in a number of forms: 'about', 'for' and 'practice in' entrepreneurship (Gibb, 2002). The 'about' form can be related to formal education (curricular: courses and seminars). Education 'for' entrepreneurship means focus on the acquisition of entrepreneurial skills through learning by doing (Pittaway, 2007). The 'practice in' can be associated with informal education, extracurricular activities, experiential learning. The varieties of techniques used to teach entrepreneurship are probably only limited by the imagination of the professors, the abilities and motivations of the students and the resources available to the university (Heriot, et al., 2008).

In order to begin a better understanding of extracurricular activities for entrepreneurship education, the first question that must be asked is what an entrepreneurial extracurricular activity is? Entrepreneurial extracurricular activities can be seen as: informal education, non-accredited students activities like: games, competitions, clubs and societies, summer schools, exchanges, mentoring, job shadowing, internships, workshops, financial support, incubation, business support, simulation case studies in enterprise education, speeches by entrepreneurs and role models, networking events and so on. (Davey, et al, 2010).

Many programs discover the need for accelerated offerings to recruit and encourage students who have entrepreneurial aspirations and/or well-developed plans. If the extracurricular activities are very well integrated into the educational process, those can provide intensive practical experience for students, and can make the connection between their theoretical notions and real-world experiences. It can also provide for students: a foundation for experiential learning, supportive environment which gives them a comfort within which to take risks and fail, aim to enhance entrepreneurial skills, raise awareness, aspirations and practical knowledge about what entrepreneurial activity means (Clark, et al., 2008).

Programs have understood for years that education in entrepreneurship requires practical application, more than other business disciplines. Beyond more traditional efforts such as internship, educational institutions are developing others ways to ensure that the students will acquire the necessary skills. The establishment of an open working and learning space can provide for students practical activities and allow the generation if ideas, space to test the manner in which they can be used in everyday practice (Higgins, et al., 2013).

The Practice Of Entrepreneurship Education Through Extracurricular Activities In Higher Education: Students Perspective 
Entrepreneurship courses require a non-traditional approach in which students must learn to embrace the challenges of operating in a business environment that favors creativity and risktaking. The promotion of extracurricular activities has become increasingly important to the University as they respond to criticism about the lack of relevancy in the classroom. Further empirical research shows that the entrepreneurship education programs and positive role models and entrepreneurs are strong incentives for students to choose an entrepreneurial career path (Fayolle et al., 2006).

Extracurricular activities are action oriented and based on experience. Action can be exposed in three parts: the act of doing, the experience received in the doing process and the learning accumulated from the experience (Pittaway, 2010). Extracurricular activities engage students in action and whether this action encourages students to acquire tacit knowledge about enterprising behavior. Extracurricular activities not only enhance learning, but they also seek to educate, inspire and encourage entrepreneurial interest and which is directed at the development of enterprising skills, either as a means to enhance employability or as a method of gaining skills relevant to future business creation (Edwards, 2001), help students manage their time better, make more informed and thoughtful decisions, and improve their ability to communicate (Kotts, 2011).

\section{Statement of the problem}

There are different reasons why the government of Ethiopia promotes the provision of entrepreneurship education in higher education institutions. Currently, Ethiopia's higher education system generates a large number of graduates every year. However, its economy is not in a position to absorb the graduates passing out, leading to an increase in the educated unemployed. In recent years, Ethiopia's population has grown very fast. Because of the history of Ethiopia and its multicultural composition, it seems impossible to have a Family Planning policy like that of China in the near future. It is likely that Ethiopia's population will continue to grow, which will consequently worsen the employment situation.

In order to catch up with the pace of developed countries, Ethiopia needs many entrepreneurs willing to make their businesses bigger. If the university students with high entrepreneurial potentials get proper training, they will have the best prospects for becoming "real" entrepreneurs. Entrepreneurship is a matter that involves everyone the government, society, and the educational institutions. If Entrepreneurship Education (EE) in Ethiopia's higher education system cannot completely address major obstacles in the pursuit of national economic development and employment, at least it can offer a start.

The existing literature shows that there is a ample research on Entrepreneurship education in the USA, Europe, and even Asia. However, little is known about the nature of entrepreneurship education in Africa with the exception of some fragmented studies (Kabongo \& Okpara, 2010; Isaacs et al., 2007). In Ethiopia, very few studies have analyzed the topic of entrepreneurship education in the context of universities. To the best knowledge of the researchers there are two studies conducted in this area. The first study was conducted by Kannan (2012) which was limited on one University and it only tried to address the course delivery of entrepreneurship education. The second study was conducted by Dugassa (2012) and it also focused on the course delver like the previous research and it tried to survey different universities that have online information ( since the data were collected online) those that do not have online information were excluded. A critical analysis of these two studies shows that it only focused on the assessment of entrepreneurship education on a course delivery aspect (formal course). However, the students entrepreneurship knowledge, skill and attitude are not developed only through the formal courses

The Practice Of Entrepreneurship Education Through Extracurricular Activities In Higher Education: Students Perspective 
offerings there are different techniques other than the formal course such as extracurricular activities which is the the focus of this study. Therefore, this study fills gap in entrepreneurship education research by examining the practice of entrepreneurship education through extracurricular in a country that was not given due attention by prior research.

\section{Research question}

The main purpose of the survey is to obtain an overview of the practice of entrepreneurship education through extracurricular activities from students perspective in Ethiopian Public Universities. Therefore, it aims to answer the following questions:

- What is the practice of entrepreneurship education through extracurricular activities in Ethiopian public universities?

- What are the main barriers in implementing entrepreneurship education through extracurricular activities in Ethiopian public universities?

\section{METHOD}

\section{Research design}

In order to examine the practice of entrepreneurship education through extracurricular activities in Ethiopian universities cross-sectional survey research design was used. This research design was used because it is appropriate to assess and describe the issue under discussion.

\section{Sample and sampling techniques}

From the total universities of the country four universities were selected by using random sampling techniques. Accordingly, Jimma University, Bahirdar University, Mezan-Teppi University, and Debre Markos University) were included as sample universities. Then seven (7) departments were selected again by using simple random sampling techniques from these sample universities. In each department the graduating class students (it is assumed that these students have a lot of experiences in participating in extracurricular activities in their stay in the university) were taken as sample of the study purposefully. Accordingly, 190 from Debere Markos university, 154 students from Bahir Dar University, 220 students from Jimma university, and 244 students from Mizan Tepi University were selected by using stratified sampling technique. Generally, a total of 808 students were taken as a sample of the study.

\section{Instrument of data collection}

Questionnaires: In order to assess the practice of entrepreneurship education through extracurricular activities in Ethiopian universities structured survey questionnaires for students were developed and administered to selected sample university students. Generally, the questionnaires were designed in a way that would help the researchers extract detailed data about the current practice of entrepreneurship education through extracurricular activities practice in the universities.

Interview: Semi-structured interview guide question was prepared based on the review of literature. Interview was conducted with some purposefully selected students in each department to triangulate the information that is collected through questionnaires.

\section{Pilot testing of the instrument}

To maintain the validity and reliability of the instrument a pilot testing was conducted by selecting one college in Jimma University. After preparing the instruments it was given for two experts from education in college Jimma University to check the validity of the items and comments were incorporated. Then the instruments were prepared and administered to sample university students and then the results were processed through SPSS. The reliability coefficient of the instrument was calculated to be (.83) which is regarded as strong correlation by Jackson (2009). Then the final

The Practice Of Entrepreneurship Education Through Extracurricular Activities In Higher Education: Students Perspective 
instruments were administered to all sample students by the researchers and enough time was given for them to fill and return.

\section{Methods of data analysis}

The data collected were analyzed based on the nature of the data. Quantitative data collected were analyzed by using descriptive statistics such as by the use of frequency, percentage and other descriptive statistics as deemed necessary. On the other hand, qualitative data collected through the use of interview were transcribed, coded based on themes and described qualitatively through the use of word narrations to support the quantitative results.

\section{RESULT}

In most universities in addition to formal curriculum entrepreneurship courses or activities to develop university students' entrepreneurship skills, behavior and mindset extracurricular activities are the dominant approach practiced which help student to participate voluntarily. Extracurricular activities are an important aspect of entrepreneurship education that can supplement the incurricular activities. Many higher education institutions have certain structures and regulations that they have to adhere to when it comes to curricula. There are often demands from the national governments on the curriculum content for the individual disciplines, and this can mean that there is little room for incorporating all the entrepreneurship activities which the institutions want, especially education in/for entrepreneurship. In such cases the institutions can make use of extracurricular entrepreneurship activities and thereby make sure that all students have the opportunity to engage in entrepreneurship if they want to.

In other words, by its very nature entrepreneurship in higher education cannot be limited to the classroom. Students interested in it and committed to it will want the opportunity to try it out to actually do it. For students drawn to business or engaged in addressing persisting social problems, entrepreneurship's emphasis on implementing new enterprises provides a constructive and practical outlet for their natural idealism and its associated enthusiasm. It can help them see how to solve problems and get things done. In this regard, the environment outside the classroom is critical. Students interested in starting their own businesses or other enterprises benefit from a campus environment that takes entrepreneurship seriously and supports it.

Hence, higher education institutions including the Ethiopian universities are expected to prepare some extracurricular activities to enrich the students' awareness of the entrepreneurship sprit. To assess these in Ethiopian context students were requested whether they have ever participated in such activities or not and the result is presented in Table 1.

Table 1: Students' participation in extracurricular activity

\begin{tabular}{|lll|}
\hline Item & $\#$ & $\%$ \\
\hline Did you ever participate in any extracurricular activities & & \\
focusing on the development of entrepreneurial & & \\
behavior, skills, knowledge? & 412 & 51.0 \\
A. Yes & 396 & 49.0 \\
B. No & & \\
\hline Total & 808 & 100 \\
\hline
\end{tabular}

The Practice Of Entrepreneurship Education Through Extracurricular Activities In Higher Education: Students Perspective

${ }^{1}$ Wudu Melese Tarekegne, ${ }^{2}$ Alebachew Hailu Gelaneh 
If you get the opportunity, do you want to participate in any extracurricular activities focusing on the development of entrepreneurial behavior, skills, knowledge?

A. Yes
B. No

662

82.3

As it is presented in Table 1, almost half of the student participants 412(51.0\%) confirmed that they have got an experience of participating in extracurricular activities focusing on the development of entrepreneurial behavior, skills and knowledge in their stay in the university. Whereas, almost equal number of the students $396(49.0 \%)$ replied that they did not get a chance to participate in any extracurricular activities. This result reveals that a significant number of students are not involved in extracurricular activity which is one of the mechanisms to develop students' entrepreneurial behavior, skills and knowledge.

Moreover, as it is presented in the above table students were asked their interest of participating in extracurricular activities focusing on the development of entrepreneurial behavior, skills, and knowledge if they get the opportunity and majority of the participants $662(82.3 \%)$ confirmed that they will participate in such activities if they get that opportunity. However, still a significant number of students respondents $142(17.7 \%)$ replied that they do not want to participate in such activities. This result shows that there are students who do not have an interest in entrepreneurship education and activities.

In order to inspire students and to give them new ideas and an overview of what happens in real life, extracurricular activities are important. To assess how frequent students are involved in some extracurricular activities, they were asked and their response is summarized in Table 2.

Table 2: How often did students perform the extracurricular activities?

\begin{tabular}{|c|c|c|c|c|c|c|c|c|}
\hline \multirow[t]{2}{*}{ Activities } & \multicolumn{2}{|l|}{$\begin{array}{l}\text { Ofte } \\
\mathrm{n}\end{array}$} & \multicolumn{2}{|c|}{$\begin{array}{l}\text { Sometime } \\
\mathrm{s}\end{array}$} & \multicolumn{2}{|l|}{ Rarely } & \multicolumn{2}{|c|}{ Never } \\
\hline & \# & $\%$ & \# & $\%$ & \# & $\%$ & \# & $\%$ \\
\hline $\begin{array}{l}\text { Participate internships outside the } \\
\text { university to tevelop } \\
\text { entrepreneurial skills }\end{array}$ & 118 & 15.1 & 198 & 25.3 & 112 & $\begin{array}{l}14 . \\
3\end{array}$ & 354 & \\
\hline $\begin{array}{l}\text { Participate on projects outside the } \\
\text { university to develop } \\
\text { entrepreneurial skills }\end{array}$ & 80 & 10.2 & 208 & 26.5 & 148 & $\begin{array}{l}18 . \\
8\end{array}$ & 350 & 44.5 \\
\hline $\begin{array}{l}\text { Partake in national/international } \\
\text { business plans/venture capital } \\
\text { competitions }\end{array}$ & 72 & 9.3 & 126 & 16.2 & 116 & $\begin{array}{l}14 . \\
9\end{array}$ & 464 & 59.6 \\
\hline
\end{tabular}

The Practice Of Entrepreneurship Education Through Extracurricular Activities In Higher Education: Students Perspective 
As it is illustrated in the Table 2 most of the students 354(45.3\%), 350 (44.5\%), and 464(59.6\%) attested that they never perform taking internships outside the university to develop entrepreneurial skills, work on projects outside the university to develop entrepreneurial skills, participate in national/international business plans/venture capital competitions respectively. From this data it is clear that students are not performing extracurricular activities.

To give students an opportunity to see the real life related to extra curricular activities company visits and matchmaking events give students the opportunity to meet real entrepreneurs. Competitions, mentoring programs and summer- school programs may develop their personal skills and prepare them better to meet the professional life. To see to what extent students are involved in such activities students were requested and the result is presented in Table 3.

Table 3: The extracurricular activities in the university

\begin{tabular}{|c|c|c|c|c|c|c|c|c|}
\hline \multirow[t]{3}{*}{ Activities } & \multirow[b]{3}{*}{ \# } & \multicolumn{7}{|c|}{ Student } \\
\hline & & \multirow{2}{*}{$\frac{\text { Often }}{\%}$} & \multicolumn{2}{|c|}{ Sometimes } & \multicolumn{2}{|c|}{ Rarely } & \multicolumn{2}{|c|}{ Never } \\
\hline & & & \# & $\%$ & \# & $\%$ & \# & $\%$ \\
\hline Seminars/workshops & 90 & 11.6 & 224 & 28.8 & 112 & 14.4 & 352 & 45.2 \\
\hline Business plan competitions & 120 & 15.3 & 298 & 38.1 & 134 & 17.1 & 228 & 29.2 \\
\hline Company visits & 50 & 6.5 & 136 & 17.7 & 148 & 19.2 & 436 & 56.6 \\
\hline $\begin{array}{l}\text { Competition events between } \\
\text { students and external } \\
\text { stakeholders }\end{array}$ & 76 & 9.8 & 216 & 28 & 110 & 14.2 & 370 & 45.8 \\
\hline
\end{tabular}

Table 3, indicates that most of the respondents 352 (45.2\%) responded that they never participate seminars/workshops that focus on entrepreneurship. Whereas, a relatively significant number of participants $224(28.8 \%)$ replied that they participated on seminars/workshops that focus on entrepreneurship sometimes.

On the other hand, students were requested how frequent they have participated in business plan competition and as it is presented in the same table a significant number of participants 298(38.1\%) confirmed that they have participated sometimes. While a considerable number of respondents $228(29.2 \%)$ verify that they never participate in business plan.

Another extracurricular activity that students are expected to participate are company visits and matchmaking events between students and external stakeholders. Most students 436(56.6\%) and $370(45.8 \%)$ assert that they have never participated in such activities. However, a considerable number of participants $216(28 \%)$ replied that they have participated in matchmaking events between students and external stakeholders/springboards sometimes. Similarly, 148 (19.2\%) of students responded that they have participate in company visit activity rarely. From this data it is clear that in Ethiopian higher education students are not allowed to participate in different extracurricular activities that help the students to develop entrepreneurship behavior.

The Practice Of Entrepreneurship Education Through Extracurricular Activities In Higher Education: Students Perspective 
Currently all higher education institutions around the world offer some kind of extracurricular activities. Accordingly, every institution makes use of extracurricular entrepreneurship activities and thereby makes sure that all students have the opportunity to engage in entrepreneurship if they want to. When the university facilitates suitable conditions for students to practice entrepreneurship activities in the university campus the universities also benefit. Student entrepreneurs bring a distinctive vitality and energy to campus life. They help make a college campus fun and exciting. Entrepreneurship is among a handful of careers most of which are not represented in the curriculum-that students can pursue while they are in college. Student entrepreneurs integrate learning with the off campus world of work, problem-solving, and achievement. They add a rich and leavening dimension to a campus culture.

The development of entrepreneurship education has been a huge focus for Education Institutions in the past years. Nevertheless, there are barriers to be crossed in order to develop and provide qualitative extra-curricular activities focused on fostering entrepreneurial mindsets, attitudes and skills. In other words, there are a lot of challenges that might hinder the dissemination of entrepreneurship programs and activities in higher education, and/or the effectiveness of this type of education. The sample students were asked to identify existing obstacles, or negative factors that might hinder these activities and their response is summarized and presented in Table 4.

Table 4: The barriers to entrepreneurship education

\begin{tabular}{|c|c|c|c|c|}
\hline & \multicolumn{4}{|c|}{ Response } \\
\hline & \multicolumn{3}{|c|}{ Apply } & \multirow{2}{*}{$\begin{array}{c}\text { Not apply } \\
\%\end{array}$} \\
\hline & \# & $\%$ & \# & \\
\hline Barriers to Entrepreneurship & 394 & 54.1 & 334 & 45.9 \\
\hline No funding available to support the entrepreneurship education & 422 & 57.8 & 308 & 42.2 \\
\hline There is no academic credibility in entrepreneurship education & 394 & 54.6 & 328 & 45.4 \\
\hline $\begin{array}{l}\text { There is a lack of good-quality entrepreneurship education } \\
\text { materials }\end{array}$ & 456 & 62.1 & 278 & 37.9 \\
\hline No support from the top management at my institution & 376 & 51.8 & 350 & 48.2 \\
\hline $\begin{array}{l}\text { At my institution no recognition is given for excellence in } \\
\text { entrepreneurship education }\end{array}$ & 356 & 49.3 & 366 & 50.7 \\
\hline $\begin{array}{l}\text { The entrepreneurship education lacks strategic integration at } \\
\text { my institution }\end{array}$ & 382 & 52.6 & 344 & 47.4 \\
\hline $\begin{array}{l}\text { The entrepreneurship education depends on the efforts of a } \\
\text { single person/a few people }\end{array}$ & 438 & 60.5 & 286 & 39.5 \\
\hline $\begin{array}{l}\text { Some of the academic staff oppose the introduction of } \\
\text { entrepreneurship education }\end{array}$ & 418 & 57.4 & 310 & 42.6 \\
\hline No demand for entrepreneurship education from the students & 332 & 45.7 & 394 & 54.3 \\
\hline
\end{tabular}

The Practice Of Entrepreneurship Education Through Extracurricular Activities In Higher Education: Students Perspective 
As shown in Table 4, students were reported major barriers for the implementations of entrepreneurship education. The first barriers identified by the students are lack of good-quality entrepreneurship education materials $(62.1 \%)$ and its dependency on the efforts of a single person/a few people $(60.5 \%)$ respectively.

The second barriers identified are lack of funding available to support the entrepreneurship education (58.7\%) and academic staffs lack of interest to the introduction of entrepreneurship education $(57.4 \%)$ respectively. The resource dimension of the survey showed that close to half of the surveyed institutions supported entrepreneurship education through short-term funding, thereby limiting the degree of commitment institutions place on developing a cohesive entrepreneurship education framework on campus.

Similarly, the responses of the interviewed students confirms the existence of the above challenge; for instance one of the respondent confirmed that "As far as I know there is no special fund to support entrepreneurship education in my university this is I feel one of the bottleneck to promote entrepreneurship education in the university."

The third most common barrier was lack of support from the top management at their institution, as indicated by students $(51.8 \%)$. From this result it is clear that the strategic barriers for entrepreneurship education are mainly that support is needed from top management and from outside stakeholders, and that it is a challenge to motivate management and make them understand the approach.

The last most common barrier was a lack of strategic integration of entrepreneurship education in their institutions, which is rated by students $(52.6 \%)$. Two of the three most common barriers among institutions were strategic in nature, suggesting the need among management to acknowledge entrepreneurship education and commit to deliver it across campus.

\section{DISCUSSION}

Entrepreneurship education can be offered in higher education institution through formal curriculum or through extracurricular activities. Sometimes the extracurricular activities are more powerful than the curricular activities because it is an important approach for the development of entrepreneurial mindsets and skills (Henry et al., 2003). In order to inspire students and to give then new ideas and an overview of what happens in real life, extracurricular activities are important.

Currently all higher education institutions around the world offer some kind of extracurricular activities. Accordingly, every institution makes use of extracurricular entrepreneurship activities and thereby makes sure that all students have the opportunity to engage in entrepreneurship if they want to. When the university facilitates suitable conditions for students to practice entrepreneurship activities in the university campus the universities also benefit. Student entrepreneurs bring a distinctive vitality and energy to campus life. They make a college campus fun and exciting. Entrepreneurship is among a handful of careers most of which are not represented in the curriculum that students can pursue while they are in college. Student entrepreneurs integrate learning with the off campus world of work, problem-solving, and achievement. They add a rich and leavening dimension to a campus culture.

The Practice Of Entrepreneurship Education Through Extracurricular Activities In Higher Education: Students Perspective 
Moreover, by its very nature, entrepreneurship in higher education cannot be limited to the classroom. Students interested in it and committed to it will want the opportunity to try it out to actually do it. For students drawn to business or engaged in addressing persisting social problems, entrepreneurship's emphasis on implementing new enterprises provides a constructive and practical outlet for their natural idealism and its associated enthusiasm. It can help them see how to solve problems and get things done. In this regard, the environment outside the classroom is critical. Students interested in starting their own businesses or other enterprises benefit from a campus environment that takes entrepreneurship seriously and supports it. However, the results of this study indicate that students are not involved in such extracurricular activities that help them to promote entrepreneurship behavior. Research studies by Co and Mitchell (2006) recommended that extracurricular activities that focus on entrepreneurship plays indispensable role for students entrepreneurial behavior.

Like any other activity the development of entrepreneurship education is affected by different barriers. In other words, there are a lot of challenges that might hinder the dissemination of entrepreneurship courses, programs and activities in higher education, and/or the effectiveness of this type of education.

Accordingly, the results of this study revealed that one of the most common barriers is lack of funding available to support the entrepreneurship education. It is clear that the level and scope of entrepreneurship education is closely linked to the amount of resources available for entrepreneurship education. So there is a natural barrier related to the amount of resources that the university is able to direct to the undertaking of entrepreneurship education.

Another barrier identified in this study is lack of support from top management and from outside stakeholders. This result is also consistent with the findings of Kuratko (2005) that indicate low support from the management body is a hindrance for the development of entrepreneurship education. It is a challenge to motivate management and make them understand the approach. The understanding might be easier to find for entrepreneurship education in the traditional sense whereas entrepreneurship education in technical or other specialized areas can be harder to get across. There is a problem of awareness and motivation within the institutions, when entrepreneurship is a priority neither for administration nor for faculties. In most cases, research publications are seen as being far more important. Therefore entrepreneurship within an institution is very much dependent on the willingness and vision of certain leaders. This is not an organizational problem, but rather a strategic one. The last barrier identified is lack of strategic integration of entrepreneurship education in their institutions. Generally, it can be said that two of the three most common barriers among institutions were strategic in nature, suggesting the need among management to acknowledge entrepreneurship education and commit to deliver it across campus.

\section{RECOMMENDATIONS}

Based on the above analysis, the following recommendations are offered:

Creating a policy on entrepreneurship education is a must when Education Institutions want to shift to entrepreneurial institutions. Every educational institution which focuses on being entrepreneurial

The Practice Of Entrepreneurship Education Through Extracurricular Activities In Higher Education: Students Perspective 
should find the resources to create an entrepreneurship department and appoint change agents that can act as spokesmen/advocates at the management level.

The opportunity of entrepreneurship education should be extended to all students in the university, regardless of their faculty or subject major through university-wide programs. This is based on the idea that entrepreneurship education is critical to create awareness of, and explore the potential for self-employment as a career option.

The objectives of entrepreneurship course should be revisited. Attempts should be made to direct the objective of the entrepreneurship program towards enhancement of the attitude of graduates towards self-employment, risk taking as well as skills needed to manage and run newly created businesses rather than just letting students learn about the functions and roles of entrepreneurship.

Encourage staff members to get involved in the entrepreneurial activities by offering incentives and create value for students through the activities provided. For a better quality of the entrepreneurship provision, the academic staff should have more possibilities to improve their skills and competence in the field of entrepreneurship education and training.

The future of entrepreneurship education needs solid foundation. All future actions, regarding the development of entrepreneurship education within educational institutions, could be more efficient if more surveys and studies are carried out. This kind of research can create a sustainable platform for initiatives; therefore, it is very important that Educational Institutions are active in providing data and taking initiatives.

Finally, regarding the implication for future research, this study investigated the current state of entrepreneurship education in Ethiopian universities. The study, however, did not cover how entrepreneurship education influences the inclination of university students towards entrepreneurial career. Future researchers should therefore try to understand entrepreneurial inclination of university students in order to determine the impact of entrepreneurship education on the attitude of graduates towards self-employment in Ethiopian context.

\section{REFERENCES}

Acs, Z J., and Szerb, L. (2007). Entrepreneurship, Economic Growth and Public Policy. Small Business Economics 28(2-3): 109-122.

Ahmad pourdaryani M.(1999). Entrepreneurship: Opinions, Definitions, Patterns. Tehran: Pardis

Brijlal, P. (2008), "The state of entrepreneurship education at tertiary institutions in the Western Cape", Journal of College Teaching \& Learning (TLC ), Vol. 5 No. 2, pp. 25-36.

Buckland, R. 2009. Private and Public Sector Models for Strategies in Universities. British Journal of Management 20: 524-536.

The Practice Of Entrepreneurship Education Through Extracurricular Activities In Higher Education: Students Perspective 
Clark G., Dawes F., Heywood A. and McLaughlin, T. (2008), Students as transfers of knowledge: The problem of measuring, International Small Business Journal 26(6): 735- 758.

Co, M.J. and Mitchell, B. (2006), "Entrepreneurship education in South Africa: a nationwide survey", Education \&Training, Vol. 48 No. 5, pp. 48-359.

Davey, T., Plewa, C. and Struwig, M. 2010. Entrepreneurship perceptions and career intentions of international students. Education + Training 53(5): 335-352.

De Silva, M. 2015. Academic entrepreneurship and traditional academic duties: synergy or rivalry?, Studies in Higher Education, DOI:10.1080/03075079.2015.1029901

Dugassa Tessema (2012), The context of entrepreneurship education in Ethiopian Universities, Management Research Review: Vol.35 Issue 3/4 4.

Edwards, L.J. (2001), Are e-clubs the answer to entrepreneurial learning? WEI Working Paper series 17.

Ertuna, Z. and Gurel, E. 2011. The moderating role of higher education on entrepreneurship. Education+Training 53(5): 387-402

Fayolle, A., Gailly, B. and Lassas-Clerc, N. (2006), Assessing the impact of entrepreneurship education programmes: a new methodology, Journal of European Industrial Training, Vol. 30 No. 9, pp. 701-20.

Gibb, A. A. (2002), In Pursuit of a New Enterprise and Entrepreneurship Paradigm for Learning: Creative Destruction, New Values, New Ways of Doing Things and New Combinations of Knowledge, International Journal of Management Reviews pp.213-32.

Henry, C., Hill, F. and Leitch, C. (2005), "Entrepreneurship Education and Training: Can Entrepreneur be Taught? Part I", Education and Training Journal, Vol. 47, Issue 2, pp. 98-111.

Heriot, K.C., Cook, R.G., Simpson, L., Parker, R. (2008), The use of micro student consulting projects as an alternative to traditional field-based student consulting projects: an exploratory study, Journal of Entrepreneurship Education, Volume 11, pp: 59-74

Higgins, D., Kelly, S. and Mirza, M. (2013), Entrepreneurial education: Reflecxive Approaches to Entrepreneurial Learning in Practice, The Journal Entrepreneurship, Vol. 22 (2) 135 - 160

Isaacs, E., Visser, K., Friedrich, C. and Brijlal, P. (2007), "Entrepreneurship education and training at the Further Education and Training (FET) level in South Africa", South African Journal of Education, Vol. 27 No. 4, pp. 613-29.

Kannan A.S. (2012).Entrepreneurship Education in Ethiopian Universities: Current Trends and Gaps ( the case of Dilla University), International Journal of Management (IJM) vol. 3 issue 3, pp. 121-130

Kirby, D.A. (2005). Entrepreneurship education: can business schools meet the challenge?, Proceedings of the 2005 San Francisco-Silicon Valley Global Entrepreneurship Research Conference, San Francisco, CA, 173-93.

Knotts, T.L., (2011), The SBDC in the classroom: providing experiential learning opportunities at different entrepreneurial stages, Journal of Entrepreneurship Education, Volume 14, 2011, pp: $25-38$

Kuratko, D. (2005), "The Emergence of Entrepreneurship Education: Development, Trends, and Challenges", Entrepreneurship Theory and Practice, p, 577-597

Pittaway, L. and Cope, J. (2007), Simulating Entrepreneurial Learning: Integrating

The Practice Of Entrepreneurship Education Through Extracurricular Activities In Higher Education: Students Perspective 
Experiential and Collaborative Approaches to Learning, Management Learning, Published by Sage Publications, Vol. 38 (2): 211-233

Shinnar, R., Pruett, M. and Toney, B. (2009). Entrepreneurship education: attitude across Campus. Journal of Education for Business 84 (3): 151-159.

Thomas, L., Billsberry, J., Ambrosini, V. and Barton, H. (2014.) Convergence and Divergence Dynamics in British and French Business Schools: How Will the Pressure for Accreditation Influence these Dynamics? British Journal of Management 25: 305-319.

Zabihi M, Moghaddasi A.(2006). Entrepreneurship, From Theory to Practice. Mashhad: Jahan Farda

Zali M, Razavie SM, Yadollahi Farsi J, Kordnaeej A.(2010). An Assessment of the Status of Entrepreneurship in Iran. Tehran: Publications of Labor and Social Security Institute

The Practice Of Entrepreneurship Education Through Extracurricular Activities In Higher Education: Students Perspective 